\title{
O Supremo Tribunal Federal e a construção do constitucionalismo multinível ${ }^{1}$
}

\author{
The Supreme Federal Court and the construction of the multilevel \\ constitutionalism
}

\section{El Supremo Tribunal Federal y la construcción del constitucionalismo multinivel}

\author{
Eduardo $\mathrm{Cambi}^{2}$ \\ Universidade Estadual do Norte do Paraná (Jacarezinho, PR, Brasil) \\ ORCID: https://orcid.org/0000-0003-4944-1256 \\ E-mail: eduardocambi@hotmail.com
}

Letícia de Andrade Porto ${ }^{3}$

Universidade Federal do Paraná (Curitiba, PR, Brasil) ORCID: https://orcid.org/0000-0002-7625-6139

E-mail: leticia.porto21@gmail.com

\begin{abstract}
Melina Girardi Fachin ${ }^{4}$
Universidade Federal do Paraná (Curitiba, PR, Brasil) ORCID: https://orcid.org/0000-0002-6250-1295

E-mail:melinafachin@gmail.com
\end{abstract}

\footnotetext{
1 CAMBI, Eduardo; PORTO, Letícia de Andrade; FACHIN, Melina Girardi. O Supremo Tribunal Federal e a construção do constitucionalismo multinível. Suprema: revista de estudos constitucionais, Brasília, v. 1, n. 2, p. 113-150, jul./dez. 2021.

2 Pós-Doutor pela Università degli Studi di Pavia (Itália). Doutor e mestre em Direito pela Universidade Federal do Paraná (UFPR). Professor do programa de pós-graduação (doutorado e mestrado) da Universidade Estadual do Norte do Paraná (UENP). Promotor de Justiça. Coordenador da Escola Superior do Ministério Público do Paraná. Presidente do Colégio de Diretores de Escolas do Ministério Público brasileiro (CDEMP). Presidente do Instituto Paranaense de Direito Processual. Membro da Academia Paranaense de Letras Jurídica. Currículo Lattes: http:// lattes.cnpq.br/6446292329035065.

${ }^{3}$ Mestra em Direitos Humanos e Democracia na Universidade Federal do Paraná (UFPR). Especialista em Ministério Público e Estado Democrático de Direito pela Fundação Escola do Ministério Público do Paraná (FEMPAR). Bacharel em Direito (Univali) e Relações Internacionais (Unisul). Assessora jurídica da Presidência do Tribunal de Justiça do Estado do Paraná (TJPR). Currículo Lattes: http://lattes.cnpq.br/4957444327036996.

4 Estágio de pós-doutoramento pela Universidade de Coimbra no Instituto de Direitos Humanos e Democracia (2019-2020). Doutora em Direito Constitucional, com ênfase em Direitos Humanos, pela PUC-SP. Professora adjunta dos cursos de graduação e pós-graduação da Universidade Federal do Paraná (UFPR). Advogada. Currículo Lattes: http://lattes.cnpq.br/1368334568714375.
} 


\title{
Resumo
}

O constitucionalismo multinível resulta da pluralidade de ordens jurídicas, onde coabitam os sistemas de proteção aos direitos humanos e as ordens constitucionais. O Ius Constitutionale Commune busca criar padrões protetivos mínimos em matéria de direitos humanos, a partir da construção e consolidação das normas internacionais garantidoras desses direitos e dos seus standards interpretativos, com o intuito de garantir a prevenção ou mitigação do sofrimento humano. A fim de buscar a implementação do constitucionalismo multinível na realidade brasileira, foram analisados precedentes no Supremo Tribunal Federal (STF). A ideia do Ius Constitutionale Commune - entoando o constitucionalismo transformador exercido pelo sistema americano na região para impactar na proteção aos direitos humanos - é adequada à realidade latino-americana, que sofre de problemas comuns de desigualdades estruturais e que, constantemente, está imersa em lutas pela afirmação da cidadania e contra a discriminação. O presente artigo foi pautado no método dialético, mediante análise bibliográfica.

\section{Palavras-chave}

Constitucionalismo multinível; Direitos humanos; Ius Constitutionale Commune; Diálogos; Supremo Tribunal Federal.

\section{Sumário}

1. Introdução. 2. O constitucionalismo multinível e a proteção dos direitos humanos. 3. O Supremo Tribunal Federal e a construção do Ius Constitutionale Commune. 4. A implementação do constitucionalismo multinível e seus mecanismos de efetividade. 5. Conclusão.

\begin{abstract}
Multilevel constitutionalism is the result from the plurality of legal orders, where systems for the protection of human rights and constitutional orders coexist. The Ius Constitutionale Commune seeks to create minimum protective standards in human rights, based on the construction and consolidation of international norms that guarantee these rights and their interpretative standards, with the aim of guaranteeing the prevention or mitigation of human suffering. In order to seek the implementation of multilevel constitutionalism in the Brazilian reality, precedents were analyzed in the Brazilian Federal Supreme Court. The idea of the Ius Constitutionale Commune - directing the transformative constitutionalism exercised by the American system in the region to impact on the protection of human rights - is appropriate to the Latin American reality, which suffers from common problems of structural inequalities and which is constantly immersed
\end{abstract}


in struggles for the affirmation of citizenship and against discrimination. This paper was based on the dialectical method, through bibliographic analysis.

\section{Keywords}

Multilevel Constitutionalism; Human Rights; Ius Constitutionale Commune; Dialogues; Brazilian Federal Supreme Court.

\section{Contents}

1. Introduction. 2. Multilevel constitutionalism and the protection of human rights. 3. The Brazilian Federal Supreme Court and the construction of the Ius Constitutionale Commune. 4. The implementation of multilevel constitutionalism and its mechanisms of effectiveness. 5. Conclusion.

\section{Resumen}

El constitucionalismo multinivel es el resultado de la pluralidad de ordenamientos jurídicos, donde conviven sistemas de protección de los derechos humanos y ordenamientos constitucionales. El Ius Constitutionale Commune busca generar estándares mínimos de protección en derechos humanos, basados en la construcción y consolidación de normas internacionales que garanticen estos derechos y sus estándares interpretativos, con el objetivo de garantizar la prevención o mitigación del sufrimiento humano. Para buscar la implementación del constitucionalismo multinivel en la realidad brasileña, se analizaron precedentes en el Supremo Tribunal Federal. La idea del Ius Constitutionale Commune - orientando el constitucionalismo transformador que ejerce el sistema americano en la región para incidir en la protección de los derechos humanos - es adecuada a la realidad latinoamericana, que adolece de problemas comunes de desigualdades estructurales y que está constantemente inmersa en las luchas por la afirmación de la ciudadanía y contra la discriminación. Este trabajo se basó en el método dialéctico, a través del análisis bibliográfico.

\section{Palabras clave}

Constitucionalismo multinivel; Derechos humanos; Ius Constitutionale Commune; Diálogos; Supremo Tribunal Federal.

\section{Índice}

1. Introducción. 2. Constitucionalismo multinivel y protección de los derechos humanos. 3. El Supremo Tribunal Federal y la construcción del Ius Constitutionale Commune. 4. La implementación del constitucionalismo multinivel y sus mecanismos de efectividad. 5. Conclusión. 


\section{Introdução}

Democracia, Estado Democrático de Direito e direitos humanos são uma tríade de ligações próximas e indissociáveis. Na nossa região os três polos ainda encontram desafios. A América Latina é a região mais desigual do planeta, assolada por brechas sociais que culminaram na pobreza extrema, com altos índices de violência generalizada, inclusive racial e de gênero, fruto de um contexto de repressão mediante o uso desproporcional da força estatal (ORGANIZAÇÃO DOS ESTADOS AMERICANOS, 2020, p. 3).

Ante as desigualdades sociais e violações estruturais na América Latina, é preciso construir um standard protetivo mínimo de direitos humanos, trazido neste trabalho pela abordagem de um constitucionalismo multinível.

O constitucionalismo multinível é fenômeno plurívoco que aponta para a estatalidade aberta e pluralidade de ordens e autoridades constitucionais. Em se falando desse mosaico, o Ius Constitutionale Commune desponta como o novo constitucionalismo latino-americano, em uma abordagem transformadora, indicando "'a mudança da realidade política e social da América Latina para a criação das condições sociais e políticas necessárias para a consolidação da democracia, do Estado de Direito e dos Direitos Humanos"' (BOGDANDY et al., 2017, p. 28).

A presença do Ius Constitutionale Commune - como estratégia de efetivação dos direitos humanos e respeito aos precedentes da Corte Interamericana de Direitos Humanos - reforça o papel dos múltiplos atores que dialogam no Sistema Interamericano, sobretudo para a criação de uma rede judicial de proteção (ALVARADO, 2015).

A hipótese de pesquisa reside em avaliar se o Supremo Tribunal Federal tem dialogado, em sua jurisprudência selecionada, com outras ordens jurídicas - como a Corte Europeia de Direitos Humanos e a Corte Interamericana de Direitos Humanos - de modo a possibilitar a construção de um constitucionalismo multinível para a ampliação e garantia dos direitos humanos no Brasil. Como meio de verificação da hipótese da presente pesquisa, foram selecionados quatro precedentes do STF: a Medida Cautelar na Arguição de Descumprimento de Preceito Fundamental (ADPF) 347, ${ }^{5}$ julgada pelo Supremo Tribunal Federal

STF, ADPF 347 MC, Tribunal Pleno, Rel. Min. Marco Aurélio, j. 9 set. 2015. 
em 2015, que resultou no reconhecimento do estado de coisas inconstitucional do sistema prisional brasileiro; o Referendo na Medida Cautelar na Ação Direta de Inconstitucionalidade 5.357, ${ }^{6}$ julgada em 2016, cujo objeto versava sobre o ensino inclusivo em todos os níveis de educação; a Medida Cautelar na ADPF $635 / \mathrm{RJ},{ }^{7}$ julgada em 2020, em que foi reconhecida a violência generalizada, mormente quanto à omissão estrutural do poder público na adoção de medidas para a redução da letalidade policial; e a ADPF $153,{ }^{8}$ julgada em 2010, que declarou constitucional a Lei de Anistia.

A fortificação da tutela dos direitos humanos em nosso contexto, sobretudo marcado pela erosão democrática provocada por populismos e autoritarismos que crescem na região, reclama complemento de fundamento jurídico e execução prática. Nesse norte, questiona-se o seguinte problema de pesquisa: na seleção de julgados pesquisados é possível verificar um diálogo entre Cortes proposto pelo Supremo Tribunal Federal em matéria de direitos humanos, de modo a compor um constitucionalismo multinível?

Para tanto, o objetivo geral da pesquisa é analisar a jurisprudência emanada em alguns casos selecionados do STF e avaliar sua interação com outras ordens jurídicas através do diálogo entre Cortes. O Supremo Tribunal Federal, como órgão de cúpula do Poder Judiciário, consubstancia-se no mais importante ator para a implementação do Ius Constitutionale Commune, na perspectiva da construção de um constitucionalismo multinível para o Brasil.

O presente artigo pauta-se por uma matriz exploratória (GIL, 2002, p. 41) baseada no método dialético, mediante análise bibliográfica, no que concerne ao estudo do constitucionalismo multinível, e na construção do Ius Constitutionale Commune para o Brasil. Também foram selecionados quatro julgados do STF, com o intuito de verificar se existem diálogos multiníveis com outros órgãos e cortes, em direitos humanos. A presente pesquisa tem o escopo de demonstrar que o diálogo em direitos humanos não deve se limitar apenas ao âmbito judicial, ainda que esta seja a análise que se pretende fazer no estudo, mas também ser ampliado à sociedade civil e às vítimas e aos operadores do Direito que formam o que Bogdandy e Ureña (2020, p. 413) denominam de comunidade de prática.

\footnotetext{
${ }^{6}$ STF, ADI 5357 MC-Ref, Tribunal Pleno, Rel. Min. Edson Fachin, j. 9 jun. 2016.

STF, ADI 635 MC, Tribunal Pleno, Rel. Min. Edson Fachin, j. 18 ago. 2020.

${ }^{8}$ STF, ADPF 153, Tribunal Pleno, Rel. Min. Eros Grau, j. 29 abr. 2010.
} 


\section{O constitucionalismo multinível e a proteção dos direitos humanos}

A pluralidade de ordens jurídicas, seja no nível internacional, regional ou nacional, enseja debate quanto às colisões e aos processos de harmonização necessários para evitar uma interpretação dissonante daquelas reveladas pelas cortes regionais e cortes internacionais de direitos humanos. Os crescentes problemas econômicos, sociais, ambientais e políticos desafiam a jurisdição constitucional a solucioná-los, apresentando como resposta a interpretação conforme os valores e princípios em consonância com os direitos humanos, com a consequente abertura da Constituição aos diplomas internacionais (RAMOS, 2011/2012).

A nova ordem pública (BOGDANDY et al., 2017), marcada por um constitucionalismo multinível, compreende a coexistência de normas e entendimentos de diferentes matrizes que dividem o mesmo espaço social. A conversão e concorrência no ordenamento jurídico, dentro do espaço nacional, é inerente ao direito internacional. Isso provoca mudanças importantes no constitucionalismo contemporâneo e contribui para a abertura do direito constitucional ao direito internacional dos direitos humanos (CAMBI; PORTO; FACHIN, 2020; RAMOS, 2011/2012).

As ordens nacionais e regionais são marcadas por uma relação de interdependência, porque ambas perseguem o objetivo comum de proteção aos direitos humanos, o que exige o diálogo permanente entre atores, sistemas jurídicos e cortes, a fim de garantir, ao máximo, a melhor interpretação em favor do indivíduo e proteção ao princípio pro persona (ALVARADO, 2015, p. 12). Essa articulação pressupõe a existência e o exercício do controle de convencionalidade e da hermenêutica a favor dos direitos humanos - mecanismos garantidores do processo de harmonização da pluralidade de ordens jurídicas.

O elemento central desta proposta do constitucionalismo transformador é, pois, o diálogo. Este novo direito constitucional deve ser um motor propulsor de interlocução entre autoridades judiciais nacionais e internacionais, sobretudo em virtude do papel central do Poder Judiciário para essa transformação (ROA, 2020, p. 3). Partindo da premissa de Robert Alexy (2005, p. 572-581), os juízes são considerados representantes argumentativos dos grupos excluídos que procuram os tribunais para obter a garantia e a proteção de seus direitos (BARROSO, 2016; ROA, 2020, p. 3). 
Assim, o Judiciário tem - desde o início do projeto constitucional papel fundamental na realização dos direitos, todavia deve possibilitar a crescente e necessária participação daqueles implicados por estes processos de afirmação jurídica:

En definitiva, uno de los elementos centrales del constitucionalismo transformador es la ampliación del acceso para los movimientos sociales y para los ciudadanos a la justicia nacional e internacional. Por esa razón, el constitucionalismo transformador destaca las sesiones itinerantes de la Corte IDH, las audiencias públicas y seguramente la agenda del futuro por la existencia de un tribunal permanente que pueda atender demandas de justicia de toda la región. Internamente, el Ius Constitutionale Commune se compromete con modelos de justicia que sean abiertos para los ciudadanos de manera que se puedan implementar los estándares internacionales sobre derechos humanos por parte de los tribunales nacionales. ${ }^{9}$ (ROA, 2020, p. 12).

O resultado do processo de harmonização das ordens jurídicas permite o desenvolvimento do Ius Constitucional Commune Interamericano - uma espécie de proteção mínima aos direitos humanos. A criação de um catálogo constitucional comum estabelece um standard de proteção, facilita a comunicação entre diferentes atores no sistema de proteção, garante a coerência do sistema jurídico, além de servir como parâmetro para a validade das normas constitucionais e internacionais. Serve, pois, como um guia para o exercício do poder - de forma a evitar excessos e violações (ALVARADO, 2015, p. 14), porque "o futuro do sistema internacional de proteção dos Direitos Humanos está condicionado aos mecanismos nacionais de implementação" (TRINDADE; VENTURA ROBLES, 2004, p. 434).

No âmbito regional do Sistema Interamericano de Direitos Humanos, o principal caminho para a aplicação do Ius Constitutionale Commune é o controle de convencionalidade, tanto na forma difusa quanto concentrada. Nesse ponto, Flávia Piovesan (2014, p. 100) sustenta haver uma

\footnotetext{
9 "Em suma, um dos elementos centrais do constitucionalismo transformador é a expansão do acesso dos movimentos sociais e dos cidadãos à justiça nacional e internacional. Por isso, o constitucionalismo transformador destaca as sessões itinerantes da Corte Interamericana, as audiências públicas e certamente a agenda do futuro pela existência de um tribunal permanente que pode atender às demandas de justiça de toda a região. Internamente, o Ius Constitutionale Commune está comprometido com modelos de justiça abertos aos cidadãos para que as normas internacionais sobre direitos humanos possam ser implementadas pelos tribunais nacionais.” (ROA, 2020, p. 12, tradução nossa).
} 
[...] crescente abertura da Corte Interamericana ao incorporar em suas decisões a normatividade e a jurisprudência latino-americana em Direitos Humanos, com alusão a dispositivos de Constituições latino-americanas e à jurisprudência das Cortes Constitucionais latino-americanas. O diálogo jurisdicional se desenvolve em dupla via: movido pelos vértices de cláusulas constitucionais abertas e do princípio pro ser humano.

Em meio à abertura ao diálogo jurisdicional, o Ius Constitutionale Commune emerge como um novo constitucionalismo latino-americano transformador, que busca superar a profunda exclusão social sob o tripé dos direitos humanos, da democracia e do Estado de Direito (BOGDANDY et al., 2017, p. 64). Afinal, os direitos e a democracia são indissociáveis, na medida em que são mutuamente necessários para a garantia e efetividade dos direitos humanos. A abertura ao diálogo, na perspectiva do Ius Commune Constitutionale, tem características muito próprias, conforme enumera Armin von Bogdandy et al. $\left(2017\right.$, p. 18) ${ }^{10}$,

Los derechos del Ius Constitutionale Commune, no obstante su anclaje universal, muestran una serie de características específicas. La primera es la importancia de grandes injusticias, sobre todo de la violencia. Esto explica algunas innovaciones latinoamericanas que han sido acogidas internacionalmente, tales como la prohibición de amnistías por violaciones graves de Derechos Humanos, el feminicidio y la desaparición forzada de personas, así como la protección especial que se le ha dado a migrantes, pueblos indígenas y personas afrodescendientes.

A permeabilidade e a abertura ao diálogo revelam-se possível por meio da interpretação do artigo 29 da Convenção Americana de Direitos Humanos, pela qual há de prevalecer a norma mais favorável e protetiva ao indivíduo. Trata-se, pois, do princípio pro persona. Os tratados em direitos humanos estabelecem padrões mínimos de proteção, “os quais constituem um piso de proteção”, ao invés de um “teto protetivo” (BOGDANDY et al., 2017, p. 63). A fim de harmonizar a

\footnotetext{
10 "Os direitos do Ius Constitutionale Commune, não obstante seu alcance universal, mostram uma série de características específicas. A primeira é a importância de grandes injustiças, sobretudo da violência. Isso explica algumas inovações latino-americanas que foram acolhidas internacionalmente, tais como a proibição de anistias por violações graves de direitos humanos, o feminicídio e o desaparecimento forçado de pessoas, assim como a proteção especial que é dada aos migrantes, povos indígenas e pessoas afrodescendentes." (BOGDANDY et al., 2017, p. 18, tradução nossa).
} 
ordem jurídica nacional diante dos ordenamentos internacionais, em respeito ao standard mínimo de proteção dos direitos humanos (PIOVESAN; FACHIN; MAZZUOLI, 2019, p. 269), é fundamental a configuração de uma rede judicial interna-internacional de proteção que potencialize a efetividade de proteção dos cidadãos, além de um equilíbrio em relação ao cenário jurídico global e às características constitucionais nacionais (ALVARADO, 2015, p. 20).

A tutela dos direitos humanos alargou-se a ponto de não se comportar mais como uma temática limitada à soberania nacional. Passou a exercer um novo espaço hermenêutico, onde coexistem ordens paralelas, que dialogam entre si e permitem a expansividade dos direitos humanos. A pluralidade de sistemas jurídicos e os desafios para a coexistência mútua colaboram para o surgimento do direito constitucional multinível, pautado pelo direito comparado, pelas trocas constitucionais e pelos intercâmbios entre os mais variados sistemas jurídicos (FACHIN, 2020). A "conversa" entre diferentes fontes "permite encontrar a verdadeira ratio de ambas as normas em prol da proteção do ser humano (em geral) e dos menos favorecidos (em especial)" (PIOVESAN; FACHIN; MAZZUOLI, 2019, p. 268-269).

Para alcançar o resultado de um diálogo eficaz em direitos humanos, em direção a um constitucionalismo transformador, é necessário afastar as limitações que busquem evitar ou mitigar as intervenções judiciais para proteger direitos econômicos, sociais, culturais e ambientais. Um constitucionalismo fraco impõe obstáculos à transformação da realidade social, uma vez que pode esvaziar o conteúdo das competências judiciais que facilitam o diálogo com outras cortes - como a Corte Interamericana de Direitos Humanos - por meio de um efetivo controle de convencionalidade (ROA, 2020, p. 4). Ademais, um constitucionalismo fraco não consegue proteger grupos vulneráveis nem reconhecer a perspectiva de classe, gênero e raça, tampouco enfrentar as violências, desigualdades e injustiças sociais estampadas em opressões estruturais e institucionais (ROA, 2020, p. 5).

Desde luego, el hecho de que los jueces asuman la función de impulsar los cambios sociales no resuelve todos los problemas, no soluciona todos los dilemas, ni materializa todas las transformaciones que este requiere. [...] Por esa razón, es deseable potenciar el momento cooperativo y dialógico para avanzar en la transición con el fin de crear los precedentes adecuados para impulsar el cambio, reaccionar frente a los problemas emergentes y enfrentar futuros retrocesos. Entre otras cosas, eso implica un cambio en la forma de construir la 
jurisprudencia, de manera que, al mismo tiempo, se piense a largo plazo y se mantenga la sensibilidad por el periodo político actual. También es un momento adecuado para reconocer que algunas herramientas deben mutar o evolucionar. Por ejemplo, las decisiones estructurales no son un mecanismo acabado, ni tampoco el fundamento de su implementación; mucho menos los casos en los que proceden o el tipo de remedios que se deben aplicar en los juicios estructurales. Desde luego, el reto de una judicatura que apueste por impulsar el cambio social es hacer un esfuerzo por mantenerse como un actor jurídico, superar las tradiciones jurídicas formalistas consolidadas antes de la transformación, evitar las interpretaciones originalistas de la Constitución y habilitar la evolución del sistema constitucional. El objetivo final es la construcción de fundamentos jurídicos sólidos para las decisiones e intervenciones que debe realizar modelo de judicatura del constitucionalismo transformador. ${ }^{11}$ (ROA, 2020, p. 7-8).

É importante compreender a evolução do sistema constitucional. As mudanças sociais rechaçam visões exclusivamente internas da Constituição, pugnando por aberturas constitucionais e ampliação do alcance de direitos e garantias fundamentais. As violações ocorridas na América Latina durante os períodos autoritários potencializaram a busca de soluções comuns para a efetivação dos direitos humanos e aumentaram a possibilidade de cooperação jurídica internacional. O multiculturalismo inerente à região americana é objeto de proteção das Constituições que buscam uma articulação com o direito internacional, por meio de cláusulas abertas e dos blocos de constitucionalidade (CAMBI, 2020, p. 285-295).

\footnotetext{
11 "É claro que o fato de os juízes assumirem a função de promover a mudança social não resolve todos os problemas, não resolve todos os dilemas, nem materializa todas as transformações que isso requer. [...] Por isso, é desejável potencializar o momento cooperativo e dialógico para avançar na transição, a fim de criar os precedentes adequados para promover mudanças, reagir aos problemas emergentes e enfrentar retrocessos futuros. Entre outras coisas, isso implica uma mudança na forma de construir jurisprudência, de forma a, ao mesmo tempo, pensar no longo prazo e manter a sensibilidade para o atual período político. Também é um momento apropriado para reconhecer que algumas ferramentas devem sofrer mutação ou evoluir. Por exemplo, as decisões estruturais não são um mecanismo acabado, nem são a base para sua implementação; muito menos os casos em que procedem ou o tipo de remédios a serem aplicados nos julgamentos estruturais. Certamente, o desafio de um Judiciário comprometido com a transformação social é se esforçar para se manter como ator jurídico, superar as tradições jurídicas formalistas consolidadas antes da transformação, evitar interpretações originalistas da Constituição e possibilitar a evolução do sistema constitucional. O objetivo final é a construção de bases jurídicas sólidas para as decisões e intervenções a serem realizadas pelo modelo jurídico do constitucionalismo transformador.” (ROA, 2020, p. 7, tradução nossa).
} 
A sentença da Corte IDH assume, portanto, "força normativa" constitucional interna, não pela sua própria vontade, mas por combinação de uma fonte internacional (especificamente o art. 68 da CADH) com as "cláusulas de abertura" de cada uma das Constituições nacionais, elegendo o juiz interamericano como "intérprete constitucional" e de "validade" da aplicação da CADH para os direitos humanos dentro dos Estados. No Brasil, essa "cláusula de abertura” vem prevista no art. $5^{\circ}$, parágrafo $2^{\circ}$, segundo o qual os direitos e garantias expressos na Constituição "não excluem outros decorrentes [...] dos tratados internacionais [de direitos humanos] em que a República Federativa do Brasil seja parte (MAZZUOLI; CARDUCCI, 2014, p. 63-64).

Esse cenário propicia o despontar do Ius Constitutionale Commune, por meio da interação entre as autoridades judiciais nacionais e a Corte Interamericana de Direitos Humanos, uma vez que o desenvolvimento do constitucionalismo transformador na região está "baseado na maior proteção dos Direitos Humanos estabelecidos nas Constituições nacionais e nos instrumentos internacionais que compõem o corpus iuris interamericano" (ROA, 2020, p. 10). Com efeito, tanto a abertura dos ordenamentos jurídicos constitucionais ao direito internacional dos direitos humanos quanto a aplicação do direito comparado favorecem essa metodologia (ROA, 2020, p. 11).

Dessa forma, a discussão, no campo do direito internacional, sobre monismo e dualismo está ultrapassada (PAGLIARINI; DIMOULIS, 2012), porque a pluralidade de ordens jurídicas, em convivência mútua e sem hierarquia, desponta como um novo paradigma constitucional - com escala, até mesmo, global. Em razão da ausência de hierarquia entre o ordenamento jurídico nacional e o regional, "é imprescindível a superação do discurso de prevalência de uma ordem sobre a outra" (FACHIN, 2020), o que possibilita uma rede de proteção, em vários níveis - originando a expressão “multinível” (FACHIN, 2020). Mais do que hierarquias, devem prevalecer as pessoas e seus direitos, quando o intérprete é norteado pelo critério da interpretação pro persona.

\section{O Supremo Tribunal Federal e a construção do Ius Constitutionale Commune}

O modelo multinivelado do constitucionalismo exige uma outra postura do Poder Judiciário. O juiz de garantia, ou juiz de proteção, foi inicialmente idealizado como o principal ator para a efetivação de um diálogo multinível, ao 
participar da ampliação hermenêutica do catálogo de direitos humanos e garantir a sua efetividade. Esse juiz exerce suas funções em nível nacional, supranacional e internacional, tutelando os direitos humano-fundamentais.

Uma rede de proteção, que atua como um conjunto de técnicas, instituições e pessoas organizadas para desenvolver funções judiciais aptas a proteger os direitos humanos, torna-se viável quando se possibilitam diálogos mútuos, sejam eles verticais - nacional e internacional - ou horizontais -, entre diferentes jurisdições nacionais. A ausência de hierarquia na rede de proteção potencializa o intercâmbio entre jurisdições diferentes - sobretudo a interação vertical.

O novo modelo constitucional tenta combater ideologias tradicionais e historicamente arraigadas na região latino-americana, na busca da superação do conservadorismo, liberalismo e radicalismo. O principal objetivo do Ius Constitutionale Commune é efetivar as promessas e garantias presentes nas Constituições latino-americanas pós período ditatorial (BOGDANDY, 2015), já que elas garantem direitos fundamentais às populações e aos grupos vulneráveis, bem como estabelecem mecanismos de ampliação da cidadania, como as cláusulas de abertura. Todavia, anos após a implementação dessas Constituições, grande parte delas ainda frustra a expectativa criada, podendo causar, também, o reconhecimento de um Estado de Coisas Inconstitucional e até mesmo inconvencional.

Ao possibilitar que o Poder Judiciário seja colocado no centro do novo desenho constitucional multinível, abre-se a oportunidade para a humanização da magistratura e para a maior efetividade dos direitos humanos (ALVARADO, 2015, p. 21-27). Afinal, todo juiz nacional é um juiz interamericano (MACGREGOR, 2011).

Nesse contexto, a Medida Cautelar na ADPF 347, julgada pelo Supremo Tribunal Federal em 2015, é um exemplo do diálogo entre cortes e da aproximação do Ius Constitutionale Commune. O reconhecimento do Estado de Coisas Inconstitucional no sistema prisional brasileiro, "decorrente de falhas estruturais e falência de políticas públicas e cuja modificação depende de medidas abrangentes de natureza normativa, administrativa e orçamentária", ${ }^{12}$ se deu com fundamento em precedente firmado pela Corte Constitucional da Colômbia,

12 STF, ADPF 347 MC, Tribunal Pleno, Rel. Min. Marco Aurélio, j. 9 set. 2015. 
pautado em três pressupostos: situação de violência generalizada de direitos fundamentais; inércia ou incapacidade reiterada e persistente das autoridades públicas em modificar a situação; a superação das transgressões a exigir a atuação não apenas de um órgão, e sim de um pluralidade de autoridades. Os direitos apontados como ofendidos se consubstanciam como fundamentais, como a dignidade da pessoa humana, a vedação da tortura e do tratamento desumano, a assistência judiciária, saúde, educação, trabalho e segurança dos custodiados.

Não se olvida que o sistema penitenciário brasileiro congrega instituições que operam com aspectos segregacionistas em relação aos grupos vulneráveis, como os negros, as pessoas com deficiência e os analfabetos. Essa seletividade perversa e desumana dificulta a reintegração desses grupos à sociedade, sendo, ao fim e ao cabo, uma espécie de apartheid indefinido, fruto das condições precárias presentes na maioria dos estabelecimentos prisionais do Brasil. ${ }^{13}$

A proposta do Ius Constitutionale Commune para promover os direitos presentes nas Cartas Constitucionais dos países latino-americanos se coaduna com o papel do Supremo Tribunal Federal, no que diz respeito à guarda da Constituição da República Federativa do Brasil (CF/1988) e à efetivação dos direitos humanos. O STF exerce influência nas instituições, a partir de um efeito desbloqueador das barreiras jurídicas (RODRÍGUEZ GARAVITO; RODRÍGUEZ FRANCO, 2010, p. 39) e indutor de políticas públicas.

Há mais: apenas o Supremo revela-se capaz, ante a situação descrita, de superar os bloqueios políticos e institucionais que vêm impedindo o avanço de soluções, o que significa cumprir ao Tribunal o papel de retirar os demais Poderes da inércia, catalisar os debates e novas políticas públicas, coordenar as ações e monitorar os resultados. Isso é o que se aguarda desse Tribunal e não se pode exigir que se abstenha de intervir, em nome do princípio democrático, quando os canais políticos apresentarem obstruídos, sob pena de chegar-se a um somatório de inércias injustificadas. Bloqueios da espécie traduzem-se em barreiras à efetividade da própria Constituição e dos Tratados Internacionais sobre Direitos Humanos. ${ }^{14}$

13 STF, ADPF 347 MC, Tribunal Pleno, Rel. Min. Marco Aurélio, j. 9 set. 2015, p. 10.

${ }^{14}$ STF, ADPF 347 MC, Tribunal Pleno, Rel. Min. Marco Aurélio, j. 9 set. 2015, p. 13. 
A decisão do STF na Medida Cautelar na ADPF 347 resultou do diálogo entre cortes e atores em direitos humanos, como a sociedade civil e a própria Comissão Americana de Direitos Humanos.

\begin{abstract}
A guarda da Constituição pelo STF pode e deve ser provocada por aqueles assim legitimados pela Constituição (art. 103, CRFB). A legitimação do partido político (art. 103, VIII) existe para possibilitar que os representantes do povo acessem e provoquem o STF a exercer a guarda da Constituição. Essa legitimação de partido político é importante porque permite que tanto a representação majoritária (maiorias) quanto a representação minoritária (minorias) tenham acesso ao STF. Ou seja, possibilita que as maiorias provoquem o STF, mas também propicia que as minorias se façam presentes e audíveis. ${ }^{15}$
\end{abstract}

O fenômeno do Estado de Coisas Inconvencional parte das violações massivas à Convenção Americana de Direitos Humanos, decorrente de omissões do Brasil quanto à tutela deficiente dos direitos fundamentais, sobretudo no contexto do sistema carcerário brasileiro (FERREIRA; ARAÚJO, 2016).

As resoluções da Corte IDH direcionadas ao Brasil em razão de reiteradas violações em direitos humanos - como nos casos da penitenciária de Pedrinhas ${ }^{16}$, Urso Branco ${ }^{17}$ e Complexo do Tatuapé da Febem ${ }^{18}$ - demonstram a omissão do Estado brasileiro para com essa parcela da população privada de liberdade. Porém, a expressão “Estado de Coisas Inconvencional” não existe na jurisprudência da Corte IDH; revela-se uma proposta doutrinária para o exercício de uma espécie de "controle de convencionalidade por omissão construtivo", apto a buscar soluções para as inúmeras violações que chegam como denúncias à Corte IDH (FERREIRA; ARAÚJO, 2016).

A previsão da audiência de custódia foi um avanço alcançado a partir do julgamento da Medida Cautelar na ADPF 347, ${ }^{19}$ o que permitiu minimizar os efeitos

\footnotetext{
15 STF, ADPF 347 MC, Tribunal Pleno, Rel. Min. Marco Aurélio, j. 9 set. 2015, p. 3-4.

${ }^{16}$ Corte IDH, Resolução de 14 de outubro de 2019.

${ }^{17}$ Corte IDH, Resolução de 7 de julho de 2004.

${ }^{18}$ Corte IDH, Resolução de 4 de julho de 2006.

19 STF, ADPF 347 MC, Tribunal Pleno, Rel. Min. Marco Aurélio, j. 9 set. 2015.
} 
nocivos da aplicação sistemática da prisão provisória. Sua fundamentação se deu com o objetivo de assegurar as garantias fundamentais previstas na Constituição da República e nos tratados de direitos humanos, a fim de "viabilizar a aplicação de medidas alternativas cautelares, como o uso de tornozeleiras eletrônicas". ${ }^{20}$ Da mesma forma, a previsão de mutirões carcerários, com o intuito de afastar irregularidades e garantir o cumprimento da Lei de Execuções Penais, com a análise da situação processual das pessoas presas, contribuiu para humanizar a aplicação das penas e conferir maior justiça ao sistema de repressão criminal.

Em 10 de dezembro de 2020, foi incluída em pauta a Reclamação 29.303/ RJ, de relatoria do Ministro Edson Fachin, cujo objeto repousa na determinação para que as autoridades realizem, no prazo de 24 horas, audiência de custódia em todas as modalidades prisionais, até mesmo prisões temporárias, preventivas e definitivas. A reclamante, Defensoria Pública do Estado do Rio de Janeiro, aduziu a superveniência da Resolução 29/2015, ato normativo editado pelo Tribunal de Justiça do Estado do Rio de Janeiro, que teria limitado a realização de audiências de apresentação somente aos casos de prisões em flagrante. Interessante notar que as inovações trazidas pela Lei 13.964/2019, conhecida por Pacote Anticrime, ao ordenamento jurídico brasileiro ampliaram as hipóteses de apresentação do custodiado ao magistrado também nos casos em que a custódia cautelar ocorrer em razão de um mandado de prisão, não se limitando apenas à hipótese de prisão em flagrante ${ }^{21}$.

Desse modo, o Supremo Tribunal Federal permite a evolução dos direitos humanos, por meio de uma hermenêutica pro persona da Constituição da República Federativa do Brasil e dos tratados em direitos humanos.

O Referendo na Medida Cautelar na Ação Direta de Inconstitucionalidade 5.357, julgada em 2016, cujo objeto versava sobre o ensino inclusivo em todos os níveis de educação, é outro exemplo da preocupação do Supremo Tribunal Federal com a tutela adequada e efetiva dos direitos humanos. Nesse caso, o STF buscou concretizar na Convenção Internacional sobre os Direitos da Pessoa com Deficiência o princípio da igualdade como fundamento de uma sociedade

\footnotetext{
20 STF, ADPF 347 MC, Tribunal Pleno, Rel. Min. Marco Aurélio, j. 9 set. 2015, p. 14.

21 "Art. 287. Se a infração for inafiançável, a falta de exibição do mandado não obstará a prisão, e o preso, em tal caso, será imediatamente apresentado ao juiz que tiver expedido o mandado, para a realização de audiência de custódia. (Redação dada pela Lei 13.964, de 2019)"
} 
democrática que respeita a dignidade humana. ${ }^{22}$ Ressaltou o compromisso ético com a pluralidade democrática adotada pela Constituição brasileira: "somente com o convívio com a diferença e com o seu necessário acolhimento que pode haver a construção de uma sociedade livre, justa e solidária, em que o bem de todos seja promovido sem preconceitos [...] (art. 3, I e IV, CRFB)". ${ }^{23}$ Portanto, o Ius Constitutionale Commune se estabeleceu a partir do exercício do controle de convencionalidade. Nesse julgado, tal controle permitiu adequar a legislação nacional aos ditames da Convenção Internacional sobre os Direitos da Pessoa com Deficiência, que influenciou a elaboração do Estatuto da Pessoa com Deficiência - Lei 13.146/2015.

Ainda, quanto ao diálogo entre cortes, Medida Cautelar na ADPF 635/ RJ, de relatoria do Ministro Edson Fachin, julgada em agosto de 2020, valeu-se dos fundamentos do caso Favela Nova Brasília vs. Brasil, julgado pela Corte Interamericana de Direitos Humanos, em que se reconheceu a omissão no Estado do Rio de Janeiro em relação à violência e letalidade das ações decorrentes de operações dos agentes de segurança pública na Favela Nova Brasília, no Rio de Janeiro. Foi reconhecida a violência generalizada, sobretudo quanto à omissão estrutural do Poder Público na adoção de medidas para a redução da letalidade policial, suscitando a necessidade de limitação das operações policiais nos perímetros próximos às escolas, além do dever de investigação em casos de suspeita de ilícitos praticados por agentes de segurança pública:

A utilização da expressão grave violação no âmbito da jurisdição constitucional permite identificar o liame não apenas entre a magnitude da violação, mas também entre suas características, ao se exigir do Tribunal que examine o tema à luz da jurisprudência das organizações internacionais de Direitos Humanos. A omissão estrutural é a causa de uma violação generalizada, cuja solução demanda uma resposta complexa do Estado, por isso, é necessário demonstrar não apenas a omissão, mas também o nexo. A necessidade de solução complexa pode ser depreendida de decisões proferidas pela Corte Interamericana de Direitos Humanos, especialmente se dela for parte o Estado brasileiro. ${ }^{24}$

\footnotetext{
22 STF, ADI 5357 MC-Ref, Tribunal Pleno, Rel. Min. Edson Fachin, j. 9 jun. 2016, p. 2.

${ }^{23}$ STF, ADI 5357 MC-Ref, Tribunal Pleno, Rel. Min. Edson Fachin, j. 9 jun. 2016, p, 4.

${ }^{24}$ STF, ADI 635 MC, Tribunal Pleno, Rel. Min. Edson Fachin, j. 18 ago. 2020, p. 3.
} 
É relevante destacar que a decisão proferida na Medida Cautelar da ADPF $635 / \mathrm{RJ}$ trouxe importantes precedentes internacionais relativos à letalidade de agentes da segurança pública, traçando um diálogo entre cortes, ao referenciar casos como Yasa vs. Turquia, da Corte Europeia de Direitos Humanos; Las Palmeras vs. Colômbia; Zambrano Vélez et al. vs. Equador; "Massacre de Mapiripán” vs. Colômbia; Almonacid Arellano vs. Chile; e Sétimo Garibaldi vs. Brasil - todos julgados pela Corte Interamericana de Direitos Humanos. Esses casos têm em comum a omissão estatal decorrente da violência e letalidade das forças armadas ou policiais.

O terrorismo de Estado e o uso letal da força pelos agentes de segurança, nos temas anteriormente postos, ressaltam a importância do tema da justiça de transição no Brasil - sua ausência ainda fundamenta violações presentes de direitos humanos. O julgamento da ADPF $153^{25}$ mostrou que, em se falando de constitucionalismo multinível, nem só de consensos vive o sistema - isto é, os diálogos comportam visões antagônicas (FACHIN, 2020, p. 70). Todavia, há que se ponderar que tais dissensos não podem contrariar o disposto na Constituição Federal e nos tratados em direitos humanos, conforme ressoa o bloco de constitucionalidade disposto no art. $5, \$ 2^{\circ}$, da CF/1988. Por meio do julgamento do Habeas Corpus 87.585/TO e do Recurso Extraordinário 466.343/SP (que estabeleceram a impossibilidade da prisão civil por dívidas no Brasil, ressalvada a hipótese de dívidas alimentares), pelo Supremo Tribunal Federal, foi estabelecida a interpretação do status de supralegalidade conferido aos tratados de direitos humanos, sendo esses superiores às leis ordinárias e inferiores à Constituição Federal - quando não aprovados segundo o quórum exposto no art. 5 , $\$ 3^{\circ}$, da Carta constitucional (CASTRO; SILVA FILHO, 2014).

De todo modo, a adoção da supralegalidade dos tratados de direitos humanos não impediu no caso da prisão do depositário infiel que se desse preferência à Convenção Americana de Direitos Humanos em relação à Constituição brasileira. E esta é a segunda inovação. O fundamento adotado para tanto foi o princípio da aplicação da norma mais favorável em direitos humanos, ainda que em um engenho de argumentação se tenha estabelecido que tal predomínio não necessariamente revoga a norma constitucional restritiva mas impede que norma infraconstitucional lhe dê eficácia. Desse modo, ao mesmo tempo em que o STF afirmou que a Constituição

25 STF, ADPF 153, Tribunal Pleno, Rel. Min. Eros Grau, j. 29 abr. 2010. 
vale mais que o tratado, assegurou que o tratado valesse mais do que qualquer lei ordinária e que no caso de norma mais favorável impedisse a regulamentação de dispositivo constitucional restritivo, prevalecendo inclusive sobre norma constitucional originária.

Tal posicionamento causa espécie quando se vislumbra a decisão do STF sobre o status da lei de anistia de 1979. A suprema corte brasileira, embora não o declare explicitamente na decisão da ADPF $n^{\circ} 153$, conferiu prevalência à Lei no $6683 / 1979$, especialmente em seu Art. $1^{\circ}, \S 1^{\circ}$, dispositivo que trata dos “crimes conexos" e que em interpretação predominante até aqui anistia agentes da ditadura que praticaram crimes de lesa humanidade, tanto sobre a Constituição de 1988 como sobre a Convenção Americana e a jurisprudência da Corte Interamericana sobre ela (CASTRO; SILVA FILHO, 2014, p. 22).

Imperioso o destaque relativo ao caso Gomes Lund e outros (Guerrilha do Araguaia) vs. Brasil, julgado pela Corte Interamericana de Direitos Humanos, que culminou na condenação do Brasil em decorrência de crimes cometidos pelo governo durante o período ditatorial na Guerrilha do Araguaia. A Corte IDH considerou que a constitucionalidade da Lei da Anistia, no Brasil, afeta "o dever internacional do Estado de investigar e punir as graves violações de direitos humanos"26.

O Supremo Tribunal Federal detém importante papel para a consecução dos direitos humanos, além de sua garantia e efetividade. Sobre eventuais conflitos entre as ordens jurídicas, a sentença do caso Guerrilha do Araguaia vs. Brasil pela Corte IDH é categórica ao afirmar que

176. Este Tribunal estabeleceu em sua jurisprudência que é consciente de que as autoridades internas estão sujeitas ao império da lei e, por esse motivo, estão obrigadas a aplicar as disposições vigentes no ordenamento jurídico. No entanto, quando um Estado é Parte de um tratado internacional, como a Convenção Americana, todos os seus órgãos, inclusive seus juízes, também estão submetidos àquele, o que os obriga a zelar para que os efeitos das disposições da Convenção não se vejam enfraquecidos pela aplicação de normas contrárias a seu objeto e finalidade, e que desde o início carecem de efeitos jurídicos. O Poder Judiciário, nesse sentido, está internacionalmente

${ }^{26}$ Corte IDH, Caso Gomes Lund e outros (“Guerrilha do Araguaia”) vs. Brasil, j. 24 nov. 2010, p. 64. 
obrigado a exercer um "controle de convencionalidade" ex officio entre as normas internas e a Convenção Americana, evidentemente no marco de suas respectivas competências e das regulamentações processuais correspondentes. Nessa tarefa, o Poder Judiciário deve levar em conta não somente o tratado, mas também a interpretação que a ele conferiu a Corte Interamericana, intérprete última da Convenção Americana.

177. No presente caso, o Tribunal observa que não foi exercido o controle de convencionalidade pelas autoridades jurisdicionais do Estado e que, pelo contrário, a decisão do Supremo Tribunal Federal confirmou a validade da interpretação da Lei de Anistia, sem considerar as obrigações internacionais do Brasil derivadas do Direito Internacional, particularmente aquelas estabelecidas nos artigos 8 e 25 da Convenção Americana, em relação com os artigos 1.1 e 2 do mesmo instrumento. O Tribunal estima oportuno recordar que a obrigação de cumprir as obrigações internacionais voluntariamente contraídas corresponde a um princípio básico do direito sobre a responsabilidade internacional dos Estados, respaldado pela jurisprudência internacional e nacional, segundo o qual aqueles devem acatar suas obrigações convencionais internacionais de boa-fé (pacta sunt servanda). Como já salientou esta Corte e conforme dispõe o artigo 27 da Convenção de Viena sobre o Direito dos Tratados de 1969, os Estados não podem, por razões de ordem interna, descumprir obrigações internacionais. As obrigações convencionais dos Estados-Parte vinculam todos seus poderes e órgãos, os quais devem garantir o cumprimento das disposições convencionais e seus efeitos próprios (effet utile) no plano de seu direito interno. ${ }^{27}$

Nesse norte, o direito à verdade encontra-se intimamente "relacionado aos princípios da transparência, accountability, e boa governança em uma sociedade democrática” (NOWAK; FACHIN, 2020, p. 132).

A necessidade de um diálogo entre cortes guarda consonância com a hermenêutica dos tratados em direitos humanos a ser realizada por juízes e tribunais no plano nacional. ${ }^{28}$ Afinal, o mecanismo de controle de convencionalidade é instrumento de compatibilização da interpretação auferida pela própria

\footnotetext{
27 Corte IDH, Caso Gomes Lund e outros (“Guerrilha do Araguaia”) vs. Brasil, j. 24 nov. 2010, p. 65-66.

28 STF, ADI 635 MC, Tribunal Pleno, Rel. Min. Edson Fachin, j. 18 ago. 2020, p. 20-21.
} 
Corte IDH da Convenção Americana de Direitos Humanos com as normativas internas brasileiras. Desse modo, a fim de tornar este mecanismo efetivo, André de Carvalho Ramos (2015, p. 408-410) enumera parâmetros indispensáveis na análise de uma decisão judicial nacional:

1) a menção à existência de dispositivos internacionais convencionais ou extraconvencionais de Direitos Humanos vinculantes ao Brasil sobre o tema;

2) a menção à existência de jurisprudência anterior sobre o objeto da lide e as consequências disso reconhecidas pelo Tribunal;

3) a menção à existência de jurisprudência anterior sobre o objeto da lide de órgãos internacionais de Direitos Humanos aptos a emitir decisões vinculantes ao Brasil;

4) o peso dado aos dispositivos de Direitos Humanos e à jurisprudência internacional.

Os julgados referidos são apenas alguns exemplos da evolução da jurisprudência do Supremo Tribunal Federal na consolidação e efetivação dos direitos humanos aqui tomados com objetivo meramente ilustrativo do crescimento do constitucionalismo multinível na jurisdição constitucional brasileira. A menção aos dispositivos convencionais, à jurisprudência nacional e internacional anterior que versam sobre objeto semelhante, assim como a valoração dos diplomas e precedentes revelam o compromisso constante havido entre a Corte Constitucional e seus jurisdicionados em matérias envolvendo direitos fundamentais e humanos.

A realidade díspar presente na América Latina torna mais difícil o processo de harmonização entre as diferentes ordens jurídicas e a efetivação de direitos humanos, sobretudo em razão das desigualdades econômicas, sociais e culturais. Contudo, há problemas comuns que merecem soluções semelhantes, que podem ser encontradas por meio de diálogos e da construção do Ius Constitutionale Commune latino-americano.

Como diz Sergio Ramírez, ex-juiz da Corte IDH, todo magistrado da América Latina é um juiz interamericano. Isso significa que os juízes nacionais também são juízes regionais - ou juízes interamericanos, no caso dos países situados na América Latina e signatários da Convenção Americana de Direitos 
Humanos. Sob a ótica regional latino-americana, as interlocuções entre magistrados permitem a implementação dos standards da Corte Interamericana de Direitos Humanos, uma vez que, em sendo os recursos efetivos nacionalmente de forma a evitar e reparar violações em direitos humanos, torna-se desnecessária a ativação do sistema regional (ALVARADO, 2015, p. 100).

Entretanto, a efetivação dos direitos humanos não é atribuição apenas do Poder Judiciário. Não se pode prescindir da interação entre os diversos atores do sistema de justiça, o que envolve a atuação do Ministério Público, tanto estadual quanto federal, da Defensoria Pública, dos advogados, assim como estudantes e especialistas que atuam como amicus curiae (FACHIN, 2020, p. 75) nas cortes nacionais e regionais. É preciso fortalecer a cultura de cumprimento dos direitos humanos por meio da expansão, horizontal e vertical, das trocas e experiências, em uma rede institucional aberta de proteção, o que favorece a construção do Ius Constitutionale Commune e engrandece a participação da sociedade civil na luta pela afirmação da cidadania.

O sistema interamericano de direitos humanos tem na sociedade civil sua força motriz, permitindo acesso de organizações sociais e uma maior proximidade com as vítimas ${ }^{29}$. Como exemplo de sucesso, todos os casos submetidos à Comissão Interamericana contra o Brasil resultaram de um processo de coordenação entre as vítimas e organizações não governamentais (ONGs), que foi tão efetivo a ponto de "litigar em uma combinação de estratégias políticas e legais, e domesticamente implementar qualquer ganho obtido na seara internacional" (BOGDANDY et al., 2017, p. 63-64).

Um dos princípios fundamentais do Ius Constitutionale Commune é, pois, a inclusão. O reconhecimento da importância da sociedade civil, das ONGs e dos cidadãos para a transformação social é fundamental para o bom funcionamento da democracia. O papel ativo da vítima e das ONGs nos procedimentos da Corte IDH se alinha ao alargamento da legitimidade dos atores aptos a dialogar em matéria de direitos humanos. Quanto ao papel exercido pela sociedade civil no âmbito do Sistema Interamericano de Direitos Humanos, Flávia Piovesan (BOGDANDY et al., 2017, p. 64) leciona que

\footnotetext{
29 Em 2009, a reforma no Regulamento da Corte Interamericana possibilitou que as vítimas apresentassem petição inicial autônoma, o que outrora só era viável pela Comissão Interamericana. Além disso, as vítimas podem acompanhar e participar efetivamente das fases processuais. Cf. FACHIN, Melina Girardi (Org.). Guia de proteção dos direitos humanos: sistemas internacionais e sistema constitucional. Curitiba: InterSaberes, 2019. p. 153.
} 
Civil society organizations do more than simply bring cases to the inter-American system; they also defend it when it is under attack. In the last "strengthening process" considered by many to have been a process to actually weaken the inter-American human rights system - civil society organizations played a crucial role in making sure the system remained strong. Overall, greater openness has been one of the main concerns in the development of the past years. Important efforts have been made to open up the inter-American system to even more public participation. Sessions are public and a strategic decision was taken to have special court sessions in different states of the region ${ }^{30}$.

São várias as possibilidades de atores aptos a dialogarem para a implementação do Ius Constitutionale Commune, em virtude da função que desempenham e do empoderamento trazido às vítimas. Um diálogo aberto pugna por discussões constantes, que permitem o aprimoramento de opiniões e experiências. Novamente, ao se pensar em um sistema movido por trocas e diálogos constantes, não se pode limitá-lo às experiências vividas por apenas um grupo, mas é necessário assegurar a mais ampla pluralidade de interlocutores de variadas classes e com diferentes interesses.

\section{A implementação do constitucionalismo multinível e seus mecanismos de efetividade}

O constitucionalismo multinível está fundado nos artigos 1.1 e 2 da Convenção Americana de Direitos Humanos, que trata da obrigação de reconhecer e proteger os direitos previstos no documento internacional, bem como no dever de adequação das normativas internas (ALVARADO, 2015, p. 41-44), e nos ajustes interpretativos oriundos das sentenças da Corte IDH, por força do controle de convencionalidade. Ademais, os artigos 8 e 25 da CADH estabelecem garantias e proteções judiciais que são inerentes ao cidadão e servem de base para o funcionamento da rede de proteção.

\footnotetext{
30 "As organizações da sociedade civil fazem mais do que simplesmente levar casos ao Sistema Interamericano; elas também os defendem quando eles estão sob ataque. No último "processo de fortalecimento", considerado por muitos como um processo para realmente enfraquecer o sistema interamericano de direitos humanos, as organizações da sociedade civil desempenharam um papel crucial para garantir que o sistema continuasse forte. Em geral, uma maior abertura tem sido uma das principais preocupações no desenvolvimento dos últimos anos. Importantes esforços têm sido feitos para abrir o Sistema Interamericano a uma participação ainda maior do público. As sessões são públicas e foi decidido que seria estratégica a realização de sessões extraordinárias em diferentes estados da região.” (BOGDANDY et al., 2017, p. 64, tradução nossa).
} 
A vinculação às sentenças da Corte IDH decorre da CADH e da submissão à jurisdição da Corte IDH. A Corte IDH formula decisões que produzem autoridade de coisa julgada internacional, com eficácia vinculante e direta às partes do litígio (CAMBI; PORTO, 2019, p. 46).

Além disso, Eduardo Ferrer Mac-Gregor, que foi Juiz Presidente da Corte IDH, ressalta a importância da vinculação dos standards interpretativos em face do ordenamento jurídico interno dos Estados signatários da Convenção Americana. As sentenças emitidas pela Corte IDH permitem a construção de standards interpretativos mínimos para a efetividade dos direitos humanos, os quais devem ser complementados e interpretados de acordo com a Convenção Americana (MAC-GREGOR, 2013).

Com efeito, a res judicata diz respeito à proteção direta para as partes da relação processual, enquanto a res interpretata se refere à tutela indireta a todos os Estados-partes da Convenção Americana, que aplicam os standards como forma de melhor interpretar os dispositivos da CADH. Em outras palavras, "as decisões da Corte IDH operam de maneira subjetiva e direta entre as partes processuais, e de maneira objetiva e indireta em face de todos os demais Estados signatários da Convenção” (CAMBI; PORTO; HEEMANN, 2019).

O standard interpretativo mínimo de efetividade da norma convencional encontra-se disposto no artigo 69 da Convenção Americana, por meio da vinculação do respeito, garantia e adequação normativa e interpretativa das decisões emitidas pela Corte IDH em relação às normas da CADH. Como consequência, a jurisprudência constitui importante instrumento de efetivação e interpretação dos direitos humanos em atendimento ao princípio pro persona (MAC-GREGOR, 2013).

É necessário observar o alcance da transmissão das sentenças emitidas pela Corte IDH, prevista no artigo 69 da CADH, conforme explica Valério Mazzuoli (PIOVESAN; FACHIN; MAZZUOLI, 2019, p. 361),

[...] Este último expediente tem finalidade claramente educativa, principalmente no caso da ação contra o Estado ser julgada procedente, uma vez que a notificação de uma sentença da Corte aos demais Estados-Partes na Convenção mostra a estes Estados que uma nova condenação ali ocorrera por conta de uma violação estatal de direitos humanos, que eventualmente pode encontrar similitude em atos seus (desses outros Estados-Partes) da mesma natureza. 
Os precedentes da Corte IDH são importantes para a constituição do corpus iuris americano, além do controle de convencionalidade, e da interpretação conforme os direitos humanos. O controle de convencionalidade possibilita a harmonização dos sistemas nacionais com os standards regionais. Sobre sua aplicação e exercício, a Corte IDH já firmou entendimento tanto para a necessidade de um controle concentrado quanto difuso, como nos casos Almonacid Arellano vs. Chile e Gelman vs. Uruguai.

Assim, o controle de convencionalidade se consubstancia em um método para

[...] acercar la justicia a las víctimas, asegurar la economía procesal, evitar la responsabilidad internacional del Estado y en últimas asegura la supervivencia del sistema gracias a su doble efecto centralizador-descentralizador en virtud del cual la CorteIDH reivindica su rol como mero agente subsidiario a la par que los jueces nacionales refuerzan su posición como garantes primarios de la protección (ALVARADO, 2015, p. 70) $)^{31}$.

A interpretação conforme os direitos humanos também é um mecanismo que, aliado ao controle de convencionalidade, permite a ampliação do escopo protetivo. Para o alcance da melhor interpretação, é necessário que haja uma

[...] técnica hermenéutica por medio de la cual los derechos y libertades constitucionales son armonizados con los valores, principios y normas contenidos en los tratados internacionales sobre Derechos Humanos signados por los Estados, así como por la jurisprudencia de los tribunales internacionales (y en ocasiones otras resoluciones y fuentes internacionales), para lograr su mayor eficacia y protección (MAC-GREGOR, 2011, p. 549) (22 $^{32}$

\footnotetext{
31 [...] aproximar a justiça das vítimas, garantir a economia processual, evitar a responsabilidade internacional do Estado e, em última instância, garantir a sobrevivência do sistema graças ao seu duplo efeito centralizadordescentralizador, com o qual a Corte Interamericana reivindica seu papel de mero agente subsidiário ao mesmo tempo que os juízes nacionais reforçam sua posição como garantidores primários de proteção. (ALVARADO, 2015, p. 70, tradução nossa)

32 [...] técnica hermenêutica por meio da qual os direitos e liberdades constitucionais são harmonizados com os valores, princípios e normas contidos em tratados internacionais de direitos humanos assinados pelos Estados, bem como pela jurisprudência dos tribunais internacionais (e às vezes outras resoluções e fontes internacionais), para alcançar maior eficácia e proteção. (MAC-GREGOR, 2011, p. 549, tradução nossa)
} 
A possibilidade de interlocução entre juízes não se limita a diálogos horizontais, mas também verticais - entre juízes nacionais e internacionais - e, ainda, mistos - entre juízes do cenário vertical e horizontal (ALVARADO, 2015, p. 85-86). Essa comunicação só mostra o quão interdependentes são os ordenamentos jurídicos, que devem conviver mutuamente e encontrar soluções comuns para os mesmos problemas.

Ao analisar as sentenças da Corte IDH, é possível estabelecer relações que conectam os países, como o período ditatorial latino-americano e as violações que provocam consequências até hoje. A origem, em comum, desses problemas gera soluções semelhantes, as quais podem ser alcançadas pelo diálogo.

Nesse contexto, a chamada "dupla via do diálogo" permite que os juízes regionais interamericanos reproduzam entendimentos exarados por juízes nacionais em suas respectivas sentenças, como os realizados nos casos Manuel Cepeda Vargas vs. Colômbia, e Cabrera Garcia Flores y Montiel vs. México (ALVARADO, 2015, p. 102). Tal interlocução deve estimular que os entendimentos comuns sejam consonantes, tanto no nível regional quanto nacional, culminando em uma espécie de rede judicial interconectada de variados atores que buscam o mesmo fim de proteção e melhor interpretação possível pro persona, por meio da integridade de um controle dinâmico e complementar.

No entanto, não só de consensos vive o constitucionalismo multinível, mas também de opiniões dissonantes. Isso se deve ao fato de o diálogo permitir uma pluralidade de concepções ${ }^{33}$, em um universo complexo. O diálogo não combina com imposições ou hierarquias, mas com respeito, criatividade e trocas mútuas. Ao contrário, "a dimensão dialógica deve ser, assim, aqui compreendida como um exercício de alteridade e cooperação em que os sujeitos reflitam entre si” (FACHIN, 2020, p. 72). A perspectiva dialógica pode ser a chave para mediar tensões e diferenças, propiciar meios inclusivos e abranger os cidadãos excluídos com um "sentido educativo e civilizatório na medida em que confronta posicionamentos distintos” (FACHIN, 2020, p. 72). Deve prevalecer a interpretação que confere melhor sustentação no âmbito das ideias, porque "coexistência não se

\footnotetext{
${ }^{33}$ Como exemplo, pode ser citado o caso que tramitou perante a Corte Constitucional Colombiana e que pugnava pela inconstitucionalidade das normas do Código Penal Colombiano que tipificam os delitos de injúria e calúnia, com base nos critérios alcançados pela Corte IDH no julgamento do caso Kimel vs. Argentina. Contudo, o juiz da Corte Constitucional Colombiana não acatou o pedido, por entender que a decisão da Corte IDH não pode ser transplantada ao âmbito nacional sem um exercício prévio de controle de convencionalidade que leve em conta as particularidades de cada ordenamento jurídico interno (ALVARADO, 2015, p. 106).
} 
traduz em consenso e concordância. O conflito produzido nessa aproximação tem resultado criativo, e dessa catarse emerge uma pluralidade interna e internacional" (FACHIN, 2020, p. 70).

Os direitos humanos não advêm, unicamente, de documentos internacionais, mas também resultam de lutas sociais históricas, em reação às violações e repressões ocorridas inúmeras vezes ao longo da história. O surgimento de "novos direitos" - como do meio ambiente saudável, liberdade sexual e bioética - abre espaço para mais discussões e o desenvolvimento de estratégias para a superação do preconceito, exclusão, marginalidade, desigualdades sociais e desproteção jurídica (NOGUEIRA, 2002).

É indispensável ultrapassar a noção de soberania estatal como um obstáculo para afastar a incidência de normas do direito internacional em âmbito interno. Os direitos humanos transcendem aos interesses exclusivos estatais. Os Estados não são os únicos sujeitos de direito internacional público aptos a amparar os direitos fundamentais de seus cidadãos. Logo, os cidadãos alçaram o posto de sujeitos de direito internacional, com a possibilidade de utilização de "mecanismos processuais eficazes para a salvaguarda dos seus direitos internacionalmente protegidos” (MAZZUOLI, [s.d.], p. 4).

Os sistemas internacionais se complementam, de modo a alcançar interações entre os mais diferentes níveis, de ordem horizontal ou vertical, produzindo teias de diálogos, como bem destaca Flávia Piovesan (s.d., p. 05):

Os sistemas global e regional não são dicotômicos, mas complementares. Inspirados pelos valores e princípios da Declaração Universal, compõem o universo instrumental de proteção dos Direitos Humanos no plano internacional. Em face desse complexo universo de instrumentos internacionais, cabe ao indivíduo que sofre violação de direito a escolha do aparato mais favorável, tendo em vista que, eventualmente, direitos idênticos são tutelados por dois ou mais instrumentos de alcance global ou regional, ou ainda, de alcance geral ou especial. Nesta ótica, os diversos sistemas de proteção de Direitos Humanos interagem em benefício dos indivíduos protegidos.

Exemplo de interação entre sistemas internacionais de direitos humanos é o julgamento, pela Corte Interamericana de Direitos Humanos, do caso Atala 
Riffo y Niñas vs. Chile, em 24 de fevereiro de 2012. A Corte, em um precedente inédito, reconheceu haver tratamento discriminatório em razão da escolha sexual da vítima. A Corte se valeu da jurisprudência de vários órgãos da Organização das Nações Unidas (ONU), assim como de diplomas internacionais, buscando, nos parâmetros internacionais, subsídios aptos a fundamentar a decisão no âmbito regional americano (PIOVESAN, 2014).

Além disso, muitas outras decisões sobrevieram, constatando uma crescente incorporação dos "parâmetros protetivos de Direitos Humanos do sistema global (ONU) nas sentenças proferidas pela Corte Interamericana, com realce à 'soft jurisprudence' fomentada pelos treaties bodies" (PIOVESAN, 2014, p. 89). Por exemplo, o caso Artavia Murillo e outros in vitro) vs. Costa Rica, em 2012, também se valeu de uma interpretação histórica, com diálogo direto com o Sistema Universal dos Direitos Humanos.

Com efeito, pode-se dizer, à luz desses exemplos, que há uma atual "interamericanização" da Corte Europeia de Direitos Humanos, e uma "europeização" da Corte Interamericana de Direitos Humanos (PIOVESAN, 2014, p. 90).

A “interamericanização" do Sistema Europeu é fruto das sentenças da Corte Europeia que buscam solucionar violações ocorridas nos países do Leste Europeu, sobretudo quanto aos crimes provocados pelos regimes totalitários, e para a criação de uma justiça de transição. Como é sabido, a América Latina passou por um período ditatorial, razão pela qual muitos crimes de tortura, desaparecimento forçado e execução sumária foram objeto de julgamento pela Corte Interamericana de Direitos Humanos. Casos como Velásquez Rodrigues vs. Honduras; Godinez Gruz vs. Honduras; Loyaza Tamayo vs. Peru; e Barrios Altos vs. Peru foram referenciados na jurisprudência da Corte Europeia, conforme relatório produzido pelo Conselho da Europa (PIOVESAN, 2014, p. 90).

Partindo da pluralidade de interlocuções possíveis e dos vários atores que compõem a rede de proteção, a efetividade dos diálogos de direitos humanos não deve, e não pode, reduzir-se ao monopólio judicial.

A Lei Maria da Penha, Lei 11.340/1996, por exemplo, foi fruto de um diálogo com a sociedade civil, mormente a organização dos movimentos feministas no Brasil, que lutava, nos anos 70 e 80, contra a absolvição de homens que haviam assassinado suas esposas em nome da "legítima defesa da honra". No caso específico de Maria da Penha Maia Fernandes, o engajamento da sociedade civil e 
de organizações não governamentais, como o Centro pela Justiça e o Direito Internacional (Cejil) e o Comitê Latino-Americano e do Caribe para a Defesa dos Direitos da Mulher (Cladem) foi fundamental para alcançar a análise pela Comissão Interamericana de Direitos Humanos, em razão da demora de mais de quinze anos do Poder Judiciário em responsabilizar o autor das violências domésticas (SÃO PAULO, [s.d.] ).

Portanto, outras formas de intercâmbio, com participação de instituições que compõem o sistema de justiça, os poderes públicos e a sociedade civil, permitem, por meio da interpretação aberta do constitucionalismo multinível, o fortalecimento do Ius Constitutionale Commune.

\section{Conclusão}

Há várias formas de efetivação dos direitos humanos. Cláusulas abertas constitucionais - como as previstas nas Constituições das democracias latino-americanas pós períodos ditatoriais -, os controles difuso e concentrado de convencionalidade e a percepção de um sistema jurídico dinâmico sem barreiras de ordem soberana são mecanismos que permitem o funcionamento do constitucionalismo multinível.

As redes de proteção se constroem e se moldam conforme as relações firmadas e as similaridades de disputas. A interdisciplinaridade é marca registrada desse novo modelo jurídico, que se traduz pela soma dos parâmetros constitucionais aos convencionais. O constitucionalismo multinível deve estar aberto ao diálogo e aos "empréstimos" de experiências, voltado à consolidação da hermenêutica mais favorável à proteção dos direitos humanos (pro persona) (PIOVESAN, 2014, p. 91). O processo de humanização do direito internacional é, pois, resultado da sua metamorfose; isto é, de mudanças e especializações que consolidaram o direito internacional dos direitos humanos.

O constitucionalismo multinível coloca o Poder Judiciário no centro das inovações transformadoras. As decisões judiciais, bem como a observância dos precedentes, acompanhadas de políticas públicas adequadas, têm o poder de modificação da realidade, quando encontram respaldo nas pretensões legítimas de grupos sociais vulneráveis (BOGDANDY et al., 2017, p. 23). Por isso, é importante, tal como fez o México, implementar um programa de qualificação 
de magistrados para aprimorar a hermenêutica dos direitos humanos, até mesmo por meio do controle de convencionalidade.

Em resposta à pergunta de pesquisa e a partir da análise exemplificativa dos precedentes do Supremo Tribunal Federal ADPF 347, ${ }^{34}$ ADI $5.357^{35}$ e ADPF $635^{36}$, é possível concluir pela evolução da jurisprudência do STF na proteção dos direitos humanos. A textura aberta da Constituição da República Federativa do Brasil - aliada à cooperação, troca de experiências e diálogos entre cortes, bem como à participação ativa de diversos atores no processo de controle de constitucionalidade/convencionalidade - tem permitido extrair da harmonização dos ordenamentos interno/internacional soluções criativas e inovadoras mais favoráveis à tutela da dignidade da pessoa humana. Nesse norte, responde-se afirmativamente quanto à verificação de um diálogo entre cortes, realizado pelo Supremo Tribunal Federal, em matéria de direitos humanos, e a consecução do constitucionalismo multinível.

As variadas estruturas multiníveis de proteção aumentam a efetividade da defesa da cidadania em virtude da constante transformação e complexidade do cenário jurídico global. Portanto, os diferentes mecanismos de proteção jurídica como o controle de convencionalidade, a interpretação conforme e os standards interpretativos emitidos pelas cortes internacionais - permitem a expansão da efetividade dos direitos humanos e contribuem para a concretização do Ius Constitutionale Commune, como meios de defesa dos grupos mais vulneráveis, promoção da justiça e transformação da realidade social.

\footnotetext{
${ }^{34}$ STF, ADPF 347 MC, Tribunal Pleno, Rel. Min. Marco Aurélio, j. 9 set. 2015.

35 STF, ADI 5357 MC-Ref, Tribunal Pleno, Rel. Min. Edson Fachin, j. 9 jun. 2016.

${ }^{36}$ STF, ADI 635 MC, Tribunal Pleno, Rel. Min. Edson Fachin, j. 18 ago. 2020.
} 


\section{Referências}

ALEXY, Robert. Balancing, constitutional review, and representation. International Journal of Constitutional Law, v. 3, n. 4, 2005, p. 572-581.

ALVARADO, Paola Andrea Acosta. Más allá de la utopía: del diálogo interjudicial a la constitucionalización del derecho internacional: la red judicial latinoamericana como prueba y motor del constitucionalismo multinivel. 2015. Tese (doutorado) Facultad de Derecho Instituto Universitario de Investigaciòn Ortega y Gasset, Universidad Complutense de Madrid, 2015.

BARROSO, Luís Roberto. Reason without vote: the representative and majoritarian function of constitutional courts". In: BUSTAMANTE, Thomas; FERNANDES, Bernardo Gonçalves. Democratizing constitutional law: perspectives on legal theory and the legitimacy of constitutionalism. Suíça: Springer, 2016, p. 71-90.

BOGDANDY, Armin von. Ius Constitutionale Commune en América Latina: una mirada a un constitucionalismo transformador. Revista Derecho del Estado, n. 34, p. 3-50, enero/jun. 2015.

BOGDANDY, Armin von et al.(ed.) Transformative constitutionalism in Latin America: the emergence of a new Ius Commune. Oxford: Oxford University Press, 2017.

BOGDANDY, Armin Von; UREÑA, René. International Transformative Constitutionalism inLatin America. The American Journal of International Law; v. 114, n. 3, July 2020, p. 403 - 442.

BRASIL. Conselho Nacional de Justiça. Observatório dos Direitos Humanos do Poder Judiciário. Brasília: CNJ, 2020. Disponível em: https://www.cnj.jus. br/observatorio/observatorio-direitos-humanos/. Acesso em: 9 dez. 2020.

CAMBI, Eduardo. Neoconstitucionalismo e neoprocessualismo: direitos fundamentais, políticas públicas e protagonismo judiciário. 3. ed. Belo Horizonte: D’Plácido, 2020. 788 p. 
CAMBI, Eduardo; PORTO, Letícia de Andrade; FACHIN, Melina Girardi. A (in)convencionalidade da prisão diante do não recolhimento do ICMS. In.: NORONHA, João Otávio de; ALBUQUERQUE, Paulo Pinto de (org). Comentários à Convenção Americana de Direitos Humanos. São Paulo: Tirant lo Blanch, 2020. p. 579-600.

CAMBI, Eduardo; PORTO, Leticia de Andrade. O Ministério Público resolutivo e proteção dos direitos humanos. Belo Horizonte: D’Plácido, 2019. 134 p.

CAMBI, Eduardo; PORTO, Letícia de Andrade; HEEMANN, Thimotie Aragon. Controle de convencionalidade pelo Ministério Público. Revista Jurídica da Corregedoria Nacional: qualidade, resolutividade e transformação social, Brasília, v. 7, p. 109-122, 2019. Edição especial: Recomendação de Aracaju. Disponível em: https://www.cnmp.mp.br/portal/images/noticias/2019/agosto/ REVISTA_JURIDICA_7_WEB.pdf. Acesso em: 9 set. 2021.

CASTRO, Ricardo Silveira; SILVA FILHO, José Carlos Moreira da. Justiça de transição e Poder Judiciário brasileiro: a barreira da Lei de Anistia para a responsabilização dos crimes da ditadura civil-militar no Brasil. Revista de Estudos Criminais, v. 53, n. 12, p. 51-87, 2014. Disponível em: https://repositorio. pucrs.br/dspace/handle/10923/11338. Acesso em: 7 abr. 2021.

FACHIN, Melina. Constitucionalismo multinível: diálogos e(m) direitos humanos. Revista Ibérica do Direito, v. 1, n. 1, jan./abr. 2020, p. 66-82.

FACHIN, Melina (org.). Guia de proteção dos direitos humanos: sistemas internacionais e sistema constitucional. Curitiba: InterSaberes, 2019. 291 p.

GIL, Antonio Carlos. Como elaborar projetos de pesquisa. 4. ed. São Paulo: Atlas, 2002.

FERREIRA, Siddharta Legale; ARAÚJO, David Pereira de. O estado de coisas inconvencional: trazendo a Corte Interamericana de Direitos Humanos para o debate sobre o sistema prisional brasileiro. Revista Publicum, Rio de Janeiro, v. 2, n. 2, p. 67-82, 2016. Disponível em: https://www.e-publicacoes.uerj.br/index. php/publicum/article/view/26042/23647. Acesso em: 9 set. 2021.

MAC-GREGOR, Eduardo Ferrer. Eficacia de la sentencia interamericana y la coza juzgada internacional: vinculación directa hacia las partes (res judicata) y indirecta hacia los estados parte de la Convención Americana (res interpretata) (sobre el cumplimiento del caso Gelman vs. Uruguay). Estudios Constitucionales, Santiago, v. 11, n. 2, p. 618-671, 2013. Disponível em: http://www.corteidh.or.cr/ tablas/r31255.pdf. Acesso em: 06 dez. 2020. 
MAC-GREGOR, Eduardo Ferrer. Interpretación conforme y control difuso de convencionalidad: el nuevo paradigma para le juez mexicano. Estudios Constitucionales, Santiago, v. 9, n. 2, p. 531-622, 2011. Disponível em: https:// scielo.conicyt.cl/pdf/estconst/v9n2/art14.pdf Acesso em: 9 set. 2021.

MAZZUOLI, Valério de Oliveira. Direitos humanos e cidadania: uma nova concepção introduzida pela Constituição Federal de 1988: (Estudo em homenagem ao Prof. Dr. José Afonso da Silva) Revista Justitia, São Paulo, [s.d.]. Sem revisão. Matérias aprovadas para publicação futura. Disponível em: http://www.mpsp. $\mathrm{mp} . \mathrm{br} / \mathrm{portal} / \mathrm{page} /$ portal/documentacao_e_divulgacao/doc_publicacao_ divulgacao/doc_gra_doutrina_civel/civel\%2033.pdf. Acesso em: 5 dez. 2020.

MAZZUOLI, Valério de Oliveira; CARDUCCI, Michele. Teoria tridimensional das integrações supranacionais: uma análise comparativa dos sistemas e modelos de integração da Europa e América Latina. Rio de Janeiro: Forense, 2014. 196 p.

NOGUEIRA, Marco Aurélio. Os direitos sociais como causas cívicas. Saúde e Sociedade, São Paulo, v. 11, n. 1, jan./jul 2002. Disponível em: http://dx.doi. org/10.1590/S0104-12902002000100004. Acesso em: 24 nov. 2020.

NOWAK, Bruna; FACHIN, Melina Girardi. Falando a verdade: diálogos em transição no Sistema Interamericano de Direitos Humanos. In: AMARAL JR, Alberto; PIOVESAN, Flávia; DANESE, Paula Monteiro (org.). 50 anos da Convenção Americana de Direitos Humanos: o sistema interamericano legado, impacto e perspectivas. 1. ed. Salvador: Juspodium, 2020. p. 129-156.

PAGLIARINI, Alexandre Coutinho; DIMOULIS, Dimitri. (org.). Direito constitucional e internacional dos direitos humanos. Belo Horizonte: Fórum, 2012. 488 p.

PIOVESAN, Flávia. Sistema Interamericano de Direitos Humanos: impacto transformador, diálogos jurisdicionais e os desafios da reforma. Revista Direitos Emergentes da Sociedade Global, Santa Maria, RS, v. 3, n. 1, jan. jun./ 2014.

PIOVESAN, Flávia; FACHIN, Melina Girardi; MAZZUOLI, Valerio de Oliveira. Comentários à Convenção Americana sobre Direitos Humanos. Rio de Janeiro: Forense, 2019. 463 p. 
PIOVESAN, Flávia. Tratados internacionais de proteção dos direitos humanos: jurisprudência do STF. Disponível em: http://www.oas.org/es/ sadye/inclusion-social/protocolo-ssv/docs/piovesan-tratados.pdf. Acesso em: 27 set. 2021.

RAMOS, André de Carvalho. Pluralidade das ordens jurídicas: uma nova perspectiva na relação entre o Direito Internacional e o Direito Constitucional. Revista da Faculdade de Direito da Universidade de São Paulo, v. 106/107, p. 497-524, jan./dez. 2011/2012.

RAMOS, André de Carvalho. Curso de direitos humanos. 2. ed. rev. atual. e ampliada São Paulo: Saraiva, 2015. 696 p.

ROA, Jorge Ernesto Roa. El rol del juez constitucional en el constitucionalismo transformador latinoamericano. Max Planck Institute Research Paper Series. n. 2020-01.

RODRÍGUEZ GARAVITO, César; RODRÍGUEZ FRANCO, Diana. Cortes y cambio social: cómo la Corte Constitucional transformó el desplazamiento forzado en Colombia. Bogotá: Dejusticia, 2010. 294 p. Disponível em: https:// www.dejusticia.org/wp-content/uploads/2017/04/fi_name_recurso_185.pdf. Acesso em: 9 set. 2021.

SÃO PAUlO (Estado). Ministério Público. História da Lei Maria da Penha. São Paulo: MPSP, [2006?]. Disponível em: http://www.mpsp.mp.br/portal/page/ portal/Violencia_Domestica/Lei_Maria_da_Penha/vd-lmp-mais/Historia_ da_lei. Acesso em: 11 dez. 2020.

SLAUGHTER, Anne-Marie. A global community of courts. Harvard International Law Journal, v. 44, n. 1, p. 191-219, 2003.

TRINDADE, Antônio Augusto Cançado; VENTURA ROBLES, Manuel E. El futuro de la Corte Interamericana de Derechos humanos. 2. ed. atual. e ampliada. San José, Costa Rica: ACNUR, 2004. 461 p.

UREÑA, René. Espejismos constitucionales: la promesa incumplida del constitucionalismo global. Revista de Derecho Público, n. 24, enero/jun. 2010 Disponível em: https://derechopublico.uniandes.edu.co/index.php?url=archivos/ derechopub/pub82.pdf\&option=com_content\&task=download\&id=82. Acesso em: 9 set. 2021. 


\section{Legislação citada}

BRASIL. [Constituição (1988)]. Constituição da República Federativa do Brasil de 1988. Brasília: Presidência da República, [2021]. Disponível em: http://www. planalto.gov.br/ccivil_03/Constituicao/Constituicao.htm. Acesso em: 9 set. 2021.

BRASIL. Lei no 11.340, de 7 de agosto de 2006. Cria mecanismos para coibir a violência doméstica e familiar contra a mulher, nos termos do $\$ 8^{\circ}$ do art. 226 da Constituição Federal, da Convenção sobre a Eliminação de Todas as Formas de Discriminação contra as Mulheres e da Convenção Interamericana para Prevenir, Punir e Erradicar a Violência contra a Mulher; dispõe sobre a criação dos Juizados de Violência Doméstica e Familiar contra a Mulher; altera o Código de Processo Penal, o Código Penal e a Lei de Execução Penal; e dá outras providências. Brasília: Presidência da República, [2021]. Disponível em: https://www.planalto. gov.br/ccivil_03/_ato2004-2006/2006/lei/111340.htm. Acesso em: 9 set. 2021.

BRASIL. Lei no 13.146, de 6 de julho de 2015. Institui a Lei Brasileira de Inclusão da Pessoa com Deficiência (Estatuto da Pessoa com Deficiência). Brasília: Presidência da República, [2021]. Disponível em: https://www.planalto.gov.br/ ccivil_03/_ato2015-2018/2015/lei/113146.htm. Acesso em: 9 set. 2021.

BRASIL. Lei no 13.964, de 24 de dezembro de 2019. Aperfeiçoa a legislação penal e processual penal. Brasília: Presidência da República, 2019. Disponível em: http://www.planalto.gov.br/ccivil_03/_Ato2019-2022/2019/Lei/L13964. htm\#art3. Acesso em: $11 \mathrm{dez} .2020$.

BRASIL. Portaria no 190, de 17 de setembro de 2020, do Conselho Nacional de Justiça. Institui o Grupo de Trabalho denominado "Observatório dos Direitos Humanos do Poder Judiciário” e dá outras providências. Brasília: CNJ, 2020. Disponível em: https://atos.cnj.jus.br/files/original164854202010065f7c9ff66d893. pdf. Acesso em: 9 dez. 2020.

ORGANIZAÇÃO DOS ESTADOS AMERICANOS. Resolución 01/2020 da Comissão Interamericana de Direitos Humanos. Pandemia y Derechos Humanos en las Americas. Disponível em: http://oas.org/es/cidh/decisiones/ pdf/Resolucion-1-20-es.pdf. Acesso em: 11 dez. 2020.

ORGANIZAÇÃO DOS ESTADOS AMERICANOS. Convenção Americana sobre Direitos Humanos. Costa Rica, 1969. Disponível em: https://www.cidh. oas.org/basicos/portugues/c.convencao_americana.htm. Acesso em: 22 nov. 2020. 


\section{Jurisprudência citada}

BRASIL. Supremo Tribunal Federal (Tribunal Pleno). Arguição de Descumprimento de Preceito Fundamental 153/DF. Relator: Min. Eros Grau, 29 de abril de 2010. Disponível em: http://redir.stf.jus.br/paginadorpub/ paginador.jsp?docTP=AC\&docID=612960. Acesso em: 8 set. 2021 .

BRASIL. Supremo Tribunal Federal (Tribunal Pleno). Medida Cautelar na Arguição de Descumprimento de Preceito Fundamental 347/DF. Relator: Min. Marco Aurélio, 9 de setembro de 2015. Disponível em: http://redir.stf.jus. $\mathrm{br} /$ paginadorpub/paginador.jsp?docTP $=\mathrm{TP} \& \operatorname{doc} \mathrm{ID}=10300665$. Acesso em: 8 set. 2021.

BRASIL. Supremo Tribunal Federal(Tribunal Pleno). Medida Cautelar na Arguição de Descumprimento de Preceito Fundamental 635/RJ. Relator: Min. Edson Fachin, 18 de agosto de 2020. Disponível em: http://www.stf.jus.br/portal/geral/ montarMenuPdfPaginado.. sp $? \mathrm{id}=754168293 \&$ tipo $=$ TP\&descricao $=$ Inteiro $\% 20$ Teor\%20ADPF\%20/\%20635\%20-\%20MC\#. Acesso em: 8 set. 2021.

BRASIL. Supremo Tribunal Federal (Tribunal Pleno). Referendo na Medida Cautelar na Ação Direta de Inconstitucionalidade 5.357/DF. Relator: Min. Edson Fachin, 9 de junho de. 2016. Disponível em: http://redir.stf.jus.br/ paginadorpub/paginador.jsp?docTP=TP\&docID=12012290. Acesso em: 8 set. 2021 .

BRASIL. Supremo Tribunal Federal. Reclamação 29.303/RJ. Relator: Min. Edson Fachin. Andamento processual disponível em: http://portal.stf.jus.br/ processos/detalhe. asp?incidente $=5329173$. Acesso em: 9 set. 2021 (sem julgamento até a presente data).

CORTE EUROPEIA DE DIREITOS HUMANOS. Case of Yasa $\boldsymbol{v}$. Turkey. Judgment of 2 September 1998. Disponível em: https://www.hr-dp.org/ files/2013/09/09/CASE_OF_YASA_v._TURKEY_.pdf. Acesso em: 23 set. 2021.

CORTE INTERAMERICANA DE DIREITOS HUMANOS. Caso Almonacid Arellano y otros vs. Chile: Sentencia de 26 de septiembre de 2006: excepciones preliminares, fondo, reparaciones y costas. Disponível em: https://www.corteidh. or.cr/docs/casos/articulos/seriec_154_esp.pdf. Acesso em: 22 nov. 2020. 
CORTE INTERAMERICANA DE DIREITOS HUMANOS. Caso Artavia Murillo y otros ("Fecundación in vitro") vs. Costa Rica: Sentencia de 28 de noviembre de 2012: excepciones preliminares, fondo, reparaciones y costas. Disponível em: https://www.corteidh.or.cr/docs/casos/articulos/seriec_257_esp. pdf. Acesso em: 23 set. 2021.

CORTE INTERAMERICANA DE DIREITOS HUMANOS. Caso Atala Riffo y niñas vs. Chile: Sentencia de 24 de febrero de 2012: fondo, reparaciones y costas. Disponível em: https://corteidh.or.cr/docs/casos/articulos/seriec_239_esp.pdf. Acesso em: 23 set. 2021.

CORTE INTERAMERICANA DE DIREITOS HUMANOS. Caso Barrios Altos vs. Perú: Sentencia de 14 de marzo de 2001: fondo. Disponível em: http://www. corteidh.or.cr/docs/casos/articulos/seriec_75_esp.pdf. Acesso em: 24 nov. 2020.

CORTE INTERAMERICANA DE DIREITOS HUMANOS. Caso Cabrera García y Montiel Flores vs. México: Sentencia de 26 de noviembre de 2010: excepción preliminar, fondo, reparaciones y costas. Disponível em: https://www. corteidh.or.cr/docs/casos/articulos/seriec_220_esp.pdf. Acesso em: 23 set. 2021.

CORTE INTERAMERICANA DE DIREITOS HUMANOS. Caso de la "Masacre de Mapiripán” vs. Colombia: Sentencia de 15 de septiembre de 2005. Disponível em: https://www.corteidh.or.cr/docs/casos/articulos/seriec_134_esp.pdf. Acesso em: 21 set. 2021.

CORTE INTERAMERICANA DE DIREITOS HUMANOS. Caso Favela Nova Brasília vs. Brasil: Sentença de 5 de fevereiro de 2018: interpretação da sentença de exceções preliminares, mérito, reparações e custas. Disponível em: https://www.corteidh.or.cr/docs/casos/articulos/seriec_345_por.pdf. Acesso em: 23 set. 2021.

CORTE INTERAMERICANA DE DIREITOS HUMANOS. Caso Garibaldi vs. Brasil: Sentença de 23 de setembro de 2009: exceções preliminares, mérito, reparações e custas. Disponível em: https://www.corteidh.or.cr/docs/casos/ articulos/seriec_203_por.pdf. Acesso em: 23 set. 2021.

CORTE INTERAMERICANA DE DIREITOS HUMANOS. Caso Gelman vs. Uruguay: Sentencia de 24 de febrero de 2011: fondo y reparaciones. Disponível em: https://www.corteidh.or.cr/docs/casos/articulos/seriec_221_esp1.pdf. Acesso em: 22 nov. 2020. 
CORTE INTERAMERICANA DE DIREITOS HUMANOS. Caso Gomes Lund e outros ("Guerrilha do Araguaia") vs. Brasil: Sentença de 24 de novembro de 2010: exceções preliminares, mérito, reparações e custas. Disponível em: https://www.corteidh.or.cr/docs/casos/articulos/seriec_219_por.pdf. Acesso em: 7 abr. 2021.

CORTE INTERAMERICANA DE DIREITOS HUMANOS. Caso Godínez Cruz vs. Honduras: Sentencia de 20 de enero de 1989: fondo. Disponível em: https://www.corteidh.or.cr/docs/casos/articulos/seriec_05_esp.pdf. Acesso em: 23 set. 2021.

CORTE INTERAMERICANA DE DIREITOS HUMANOS. Caso Kimel vs. Argentina: Sentencia de 2 de mayo de 2008: fondo, reparaciones y costas. Disponível em: https://www.corteidh.or.cr/docs/casos/articulos/seriec_177_esp. pdf. Acesso em: 21 set. 2021.

CORTE INTERAMERICANA DE DIREITOS HUMANOS. Caso Las Palmeras vs. Colombia: Sentencia de 26 de noviembre de 2002: reparaciones y costas. Disponível em: https://www.corteidh.or.cr/docs/casos/articulos/seriec_96_esp. pdf. Acesso em: 21 set. 2021.

CORTE INTERAMERICANA DE DIREITOS HUMANOS. Caso Loayza Tamayo vs. Perú: Sentencia de 17 de septiembre de 1997: fondo. Disponível em: https://www.corteidh.or.cr/docs/casos/articulos/seriec_33_esp.pdf. Acesso em: 23 set. 2021.

CORTE INTERAMERICANA DE DIREITOS HUMANOS. Caso Manuel Cepeda Vargas vs. Colombia: Sentencia de 26 de mayo de 2010: excepciones preliminares, fondo, reparaciones y costas. Disponível em: https://www.corteidh. or.cr/docs/casos/articulos/seriec_213_esp.pdf. Acesso em: 21 set. 2021.

CORTE INTERAMERICANA DE DIREITOS HUMANOS. Caso Velásquez Rodriguez vs. Honduras: Sentencia de 29 de julio de 1988: fondo. Disponível em: https://www.corteidh.or.cr/docs/casos/articulos/seriec_04_esp.pdf. Acesso em: 23 set. 2021.

CORTE INTERAMERICANA DE DIREITOS HUMANOS. Caso Zambrano Vélez y otros vs. Ecuador: Sentencia de 4 de julio de 2007: fondo, reparaciones y costas. Disponível em: https://www.corteidh.or.cr/docs/casos/articulos/ seriec_166_esp1.pdf. Acesso em: 21 set. 2021. 
CORTE INTERAMERICANA DE DIREITOS HUMANOS. Resolução de 7 de julho de 2004: medidas provisórias a respeito da República Federativa do Brasil: caso da Penitenciária Urso Branco. Disponível em: http://www.corteidh. or.cr/docs/medidas/urso_se_04_portugues.pdf. Acesso em: 6 dez. 2020.

CORTE INTERAMERICANA DE DIREITOS HUMANOS. Resolução de 4 de julho de 2006: medidas provisórias e solicitação de ampliação de medidas provisórias com respeito à República Federativa do Brasil: caso das crianças e adolescentes privados de liberdade no "Complexo do Tatuapé" da Febem. Disponível em: http://www.corteidh.or.cr/docs/medidas/febem_se_03_ portugues.pdf. Acesso em: $6 \mathrm{dez} .2020$.

CORTE INTERAMERICANA DE DIREITOS HUMANOS. Resolução de 14 de outubro de 2019: medidas provisórias a respeito do Brasil: assunto do Complexo Penitenciário de Pedrinhas. Disponível em: http://www.corteidh. or.cr/docs/medidas/pedrinhas_se_03_por.pdf. Acesso em: 6 dez. 2020. 